\title{
Soft Tissue Sarcoma of the Abdomen and Thoracic Visceral Organs pT2 TNM Finding v8
}

National Cancer Institute

\section{Source}

National Cancer Institute. Soft Tissue Sarcoma of the Abdomen and Thoracic Visceral

Organs pT2 TNM Finding v8. NCI Thesaurus. Code C136735.

Soft tissue sarcoma of the abdomen and thoracic visceral organs with tumor extending into tissue beyond organ. (from AJCC 8th Ed.) 